\section{Both eminent and neglected}

\section{David Knight}

William Whewell: A Composite Portrait. Edited by Menachem Fisch and Simon Schaffer. Oxford University Press: 1991. Pp.403. £47.50, $\$ 45$.

WiLliam Whewell was one of the great pundits of nineteenth-century science. President of the British Association, twice president of the Geological Society, and then master of Trinity College, Cambridge, he was a meritocrat whose career shows the social mobility possible for the able scientist. He actually coined the word 'scientist', as well as 'anode', 'cathode' and 'ion', and the geological categories 'uniformitarian' and 'catastrophist'.

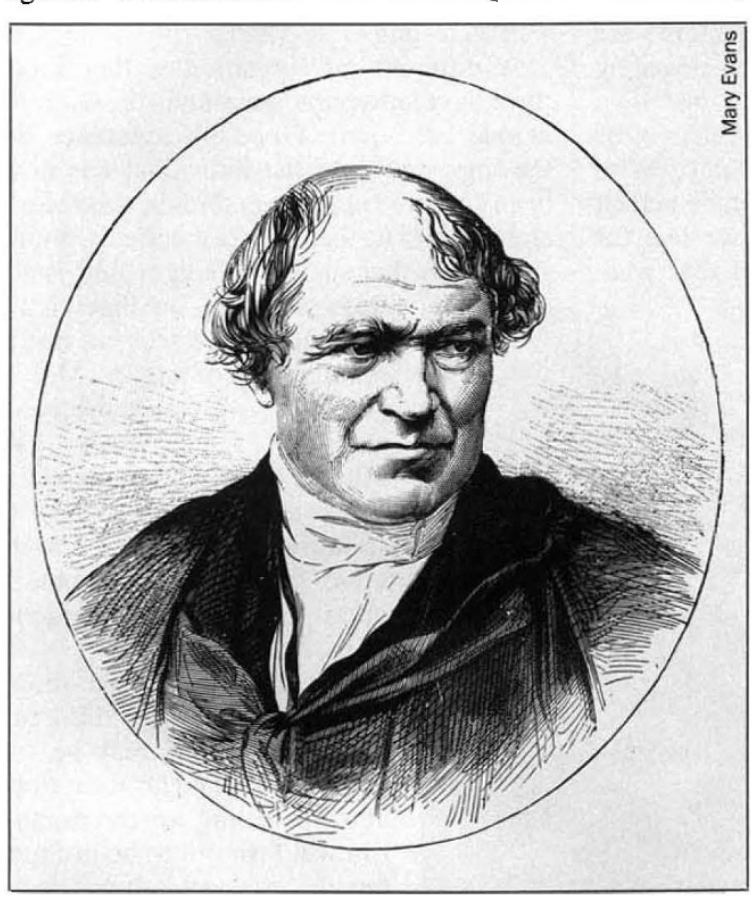

William Whewell (1794-1866) - 'science was his forte and omniscience his foible'

With his treatises, he might almost be said to have invented history and philosophy of science as academic subjects. He also wrote on moral philosophy and theology: in a famous quip by Sydney Smith, science was said to be his forte and omniscience his foible.

Given his central position in the intellectual world of the mid nineteenth century, it is surprising how quickly he was forgotten: perhaps because he stood out like a Canute against the rising tide of specialization. It is very good that we should have in William Whewell: A Composite Portrait a series of essays about him, because they illuminate the theory and practice of the science of his day, and because some of his thoughts are still relevant to understanding scientific method.

His most famous books were the History and Philosophy of the Inductive Sciences
$(1837,1840)$; in which in opposition to John Herschel, John Stuart Mill and 'baconian' orthodoxy he proposed that good science consisted of authentic facts ordered by the active mind; which gave to each science its appropriate 'fundamental idea'. This determined its particular level in the hierarchy: chemistry required more than mechanical principles, and biology more than chemical ones. The unity of the sciences for Whewell would not be achieved by the reduction of them all to mechanics or some other basis; it was a matter of sharing a common inductive method.

The word 'science' in Whewell's time embraced any definite body of knowledge, and he hoped to see his sophisticated version of the inductive process making political economy and moral philosophy genuinely scientific. He believed that speculative and deductive thinkers, D. Ricardo in economics and utilitarians such as W. Paley and J. Bentham in ethics, had gone badly astray; as had P. S. Laplace in seeing no need of God in his deterministic cosmos. As a teacher, he distinguished 'permanent' subjects like geometry and classics as being the best discipline for young minds, who could come on to 'progressive' sciences like chemistry later; and he was thus a conservative in curriculum reform at Cambridge.

A composite portrait is an interesting idea, and on the whole it works extremely well: like a series of spotlights following an actor, the various authors illuminate him from different angles, and they have mostly got him in focus and written clearly. There is of course some overlap, and some disagreement: over whether Whewell can be described as a liberal Anglican, for example, and whether Darwin's Origin of Species is a good example of Whewell's 'Consilience of Inductions' or not.

There is still room for a biography, because there are gaps here; and there still seems to be a problem about Whewell's reputation and the reception of his ideas. Although he was so celebrated, his philosophy was not taken up until the twentieth century, when he was seen as a precursor of Popper, and when physics has very different fundamental ideas from those of 1850 . It may be that he lived too long, surviving as a living fossil into the darwinian era; or conversely that his ideas were ahead of his time. But to be both eminent and neglected is indeed curious.

David Knight is in the Department of Philosophy, University of Durham, 50 Old Elvet, Durham DH1 3HN, UK.

\section{Coffee-table enzymology}

\section{Richard Perham}

Discovering Enzymes. By David Dressler and Huntington Potter. Freeman: 1991. Pp.264. £16.95, \$32.95.

"WHAT we want is a story that starts with an earthquake and works its way up to a climax." David Dressler and Huntington Potter, authors of the beautifully produced Discovering Enzymes, approvingly quote Samuel Goldwyn and clearly set out to follow the injuction: no other book on enzymes that I know begins with the Big Bang and six pages and several billion years later, can be found rhapsodizing on the part played by enzymes in "[guiding] molecules across the threshold of life". Heady stuff, but accompanied by some exquisite colour photographs: a rock formation, a seashore, a developing embryo, a Jan Breughel, a collection of neurons (or is it nature imitating art - a Jackson Pollock? No, it is neurons), a blood clot, a silk moth emerging from a cocoon.

We then take a step back and are given an animated history of the discovery of enzymes. This too is richly illustrated (Jackques-Louis David's celebrated portrait of Antoine Lavoisier and his wife, for example - no enzymologist works like that today!) and is full of interesting personalization (von Baeyer's sour comment on Eduard Buchner, his former pupil, who crucially discovered cell-free fermentation, "This will bring him fame, even though he has no chemical talent". (Buchner was awarded the Nobel Prize for Chemistry in 1907.) The concepts of specificity, the lock-and-key hypothesis and the identification of enzymes as proteins (not forgetting ribozymes) are handled well. But I am not persuaded that it was wise to limit the discussion of enzyme structure and reaction mechanism almost entirely to chymotrypsin and related enzymes. The serine proteinases have an honourable place in past and present enzymology but it is strange to find no mention of lysozyme, of the haem proteins, of kinases or dehydrogenases, of folding domains or quarternary structure. Chymotrypsin is used to good effect in illustrating many features of enzymes, and the text conveys the excitement that unravelling the structure and function of a protein can bring, but we are denied a fuller picture of the extraordinary (and beautiful) range of structure-function relationships in enzymes. It also eliminates reference to coenzymes and cofactors, without which many enzymes cannot function and no metabolic pathway can exist.

Where the extended discussion of serine proteinases does take us is into the biochemistry of blood clotting and fibrinolysis. This allows an introduction to enzyme cascades and signal amplification and the potential for enzyme therapy. To conclude, 